\title{
Teaching and Learning Economic Creativity: How to Overcome Uncertainty in Realizing Creative New Concepts That Have a Value? How the CRAP System - Coordination \& Registration of Action Points and External Assessment Generates Possible Solutions to CreateValue of New Concepts?
}

\author{
Henk Roelofs ${ }^{1, *}$, Adriaan Nieuwenhuis ${ }^{2}$ \\ ${ }^{1}$ School of Business, Stenden University for Professional Education, the Netherlands \\ ${ }^{2}$ School of Education, Stenden University for Professional Education, the Netherlands
}

Copyright $\odot 2016$ by authors, all rights reserved. Authors agree that this article remains permanently open access under the terms of the Creative Commons Attribution License 4.0 International License

\begin{abstract}
How do we identify tools that can overcome uncertainty in realizing value with students using their 'idea creativity' in generating and developing ideas in new concepts? Tools that better fit in the mindset of the new generations. The major question of idea creativity, especially in an educational environment is: How to determine and assess such "value"? In general, a teaching and learning process of idea creativity for new concepts that have value has an uncertain result. You cannot plan successes in advance. Contemporary education needs teaching methods in a setting that has the characteristics of the mindset of the new generation: twitch speed, multi-tasking, nonlinear approaches, connected, collaborative, active, and learning by playing, instant payoff, fantasy, and technology as friend. The 'connectivity learning' demands new approaches to monitor and coordinate collective learning processes - a demand driven change in teaching, caused by a demand driven learning. This dynamic complex, mostly non-linear learning processes of realizing value by students that develop new ideas into new concepts, can monitored by CRAP (coordination registration of action points) and G-CRAP (group coordination registration of action points). Using the systems, make it possible to integrate and apply the connectivity opportunities in lessons, and also to coordinate and measure learning progress, both individually and collectively. In almost every business organization the need exists to innovate continuously their products and services. The assessment of the course is at the end by presenting the results to the specific client who has asked for specific innovative solutions. Examples are: find innovative concepts
\end{abstract}

for bed \& breakfast companies, for applying specific LED lights, for a language game, for new products in the "seniors-economy", etc. Students carried out these assignments, using CRAP and G-CRAP. It also made clear that the authentic context of this learning process is realized by the key characteristic: creating added value. The presentations were held for entrepreneurs, who could benefit from the innovative concepts. They had to spend their time and energy to validate the presentations and expect "good ideas" for their invested time. One of the students expressed beautifully: "In education there is a critical dividing line between sufficient (pass) and not sufficient (fail), but in business there is a critical dividing line between good and not good. That is something entirely different."

Keywords Connectivity Learning, Coordination Registration Action Points (CRAP), Monitoring, the Value of Creativity

\section{Introduction}

Creativity is one of the skills our students need to develop, to be prepared for this 21 st Century. All kinds of words are used to characterize the competencies and skills needed to function in the twenty-first century: cross-curricular competencies, widely applicable skills, key competencies, core competencies, complex skills, "soft skills", but the most common is "21st century skills". But whatever words are 
used, "creativity" is one of the elements when these $21 \mathrm{st}$ century skills are specified. Used in the context of ways of thinking (creative and innovative thinking, critical thinking, problem solving, decision making, learning to learn). In our society, creativity is what keeps us competitive in the near future.

In learning and teaching creativity we unleash the potential of our students which is quite a different piece of cake than (over-) feed them with knowledge according to clear formats. Of course like each human being, uncertainty is not preferred. Also students are sometimes uncomfortable when clear guidance is withheld. On the other hand, it is just that that sparks curiosity to find out how a problem can be solved by themselves. The result is their solution to the real life practical problem, not the theoretical case of the book with one right solution in the back. (See "The answer is in the back, but don't look" by Ken Robinson [4] in RSA Animate Changing Education Paradigms at https://www.youtube.co $\mathrm{m} /$ watch? $=\mathrm{zDZFcDGpL4U}$ )

Referring to Bradshaw, Langley and Simon [5] and Simon [6], Cohen and Levinthal [7] suggest that the necessary preconditions for successful learning do not differ from the preconditions required for problem solving and for the creative process: "The prior possession of relevant knowledge and skills is what gives rise to creativity, permitting the sorts of associations and linkages that may have never been considered before." (Cohen and Levinthal [7])

We are interested in the role of creativity, especially we on the role of creativity that stimulates innovation with a value on a market. Creativity is defined as the production of new and useful ideas concerning products, services, processes and procedures (e.g. Oldham \& Cummings [8], Amabile [9]). Creativity is for example, an essential ingredient of innovative entrepreneurship which we usually see as a result of out-of-the-box thinking. Entrepreneurs work for markets and innovation is an invention with a value on a market. According to Waalkens [10] innovation and creativity are intrinsically related. We advocate that in education the subject of creativity has to be particularly addressed. If the ambition is to bring our students to their full potential, creativity is absolutely necessary.

\section{Questions and Objectives}

But how to assess creativity? How do we identify tools that can overcome uncertainty in realizing value with students using their creativity in generating ideas and develop these ideas in new concepts? Tools that better fit in the mindset of the new generations, and that can be applied in any modern classrooms.

In our lectures "conceptual thinking", we compare the finding new useful concepts as a result of creative thinking often with the process of digging gold in Alaska: there is an awful lot of mud, rocks, stones etc. to be handled in order find these small pieces of gold.

In assessing the value of new concepts the usefulness is a key element. Creativity to generate ideas which are developed to new useful concepts that show value, is here regarded as "idea creativity". Referring De Bono [1], as he states: "There is a language problem with our understanding of the word 'creativity'. As we understand it, if you create something that was not there before, then you are creative. But this may not necessarily be a good thing. You may have just created a mess. This leads to the notion that creativity is just being different for the sake of being different which is what far too many creative people believe. If doors are normally rectangular and you suggest a triangular door, that is not creative unless you can show value for the new shape. The problem then is that the word 'creative' does not distinguish between artistic creativity - as we understand it and idea creativity, which helps with our thinking. That the result is something new is enough for us to term it 'creativity'.

That is why it was necessary to invent the term 'lateral thinking' to refer specifically to idea creativity. Although my thinking is quite widely used in the artistic world (especially in music), I am writing here about idea creativity.

\section{Approach}

Contemporary education need teaching methods where students have to acquire competences in a setting that has all the characteristics of the mindset of this new generation (see Veen [2], Prensky [3]) : twitch speed, multi tasking, non linear approaches, connected, collaborative, active, and learning by playing, instant payoff, fantasy, and technology as friend.

Nowadays this is the standard context for any job. Communication is more complex, visual, and faster and more complete. The globalized society uses network organizations and information systems to create added value. The 'connectivity learning' demands new approaches to monitor and coordinate collective learning processes - a demand driven change in teaching, caused by a demand driven learning of the new generation.

New learning methods are needed to cultivate the talents of our new generations, since the characteristics of today's society have changed the mindset of these new generations. We believe that the future of education should focus on the effectiveness of the learning situation, instead of the use of standard books as a starting method. Prensky [3], and Veen and Vrakking [11] presume that the current generation of students follows different study methods than the generation before, simply because they are brought up with the new ICT technology, learning through computer screens, icons, sound, games, exploration and show non-linear learning behaviour

Veen [12] showed the change in teaching needed to cope with the learning attitude of students in the today's world. In his book, Homo Zappiens and the Need for New Education Systems, he states that, "Experiencing these digital 
information flows, kids develop an exploratory learning approach trying to give meaning to the information provided." In a fascinating presentation (see Figure 1), he showed us the development of our students, due to the technological development in ICT. It made very clear that as the world is changing, so should the educational world change.

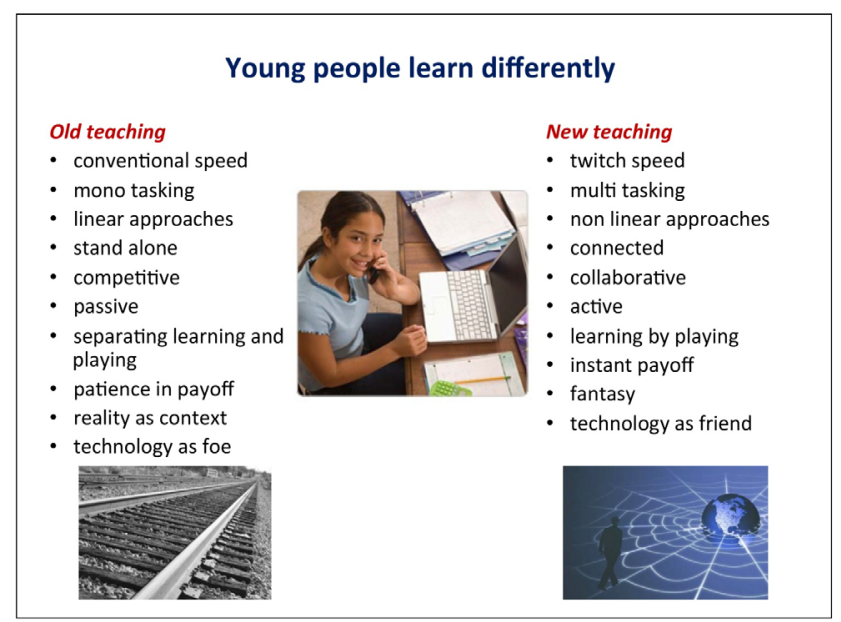

Figure 1. Old teaching vs. New Teaching

\section{Coordination and Registration of Action Points (CRAP)}

The idea to regard each lesson as a structural meeting and use the techniques of organizing effective meetings to organize effective learning processes has been developed as a result of our experiences with authentic learning environments. The developed "edupreneurial method" focused on the use of positive emotions to support learning processes: "success drives success". Kotler [13] in his textbook on Marketing defines learning as 'changes in an individual's behavior arising from experience' The use of an "action point system" (CRAP, coordination \& registration of action points \& G-CRAP, group coordination \& registration of action points) to measure the development of complex learning processes is pointed out as a system that realizes connectivity learning using the modern ICT-opportunities. Also the 'changes in individual behavior arising from experience' can be assessed in a simple way, due to the experiences of conducted actions.

The new generation is born in an era of digital gadgets, as a result of which, the threshold to communicate the knowledge and information has lowered substantially. The flow of information is enormous and filtering of the right information and responding to the right stimulations has become more relevant than ever.

With the technological progress, the communication nowadays has become totally different: it is more complex, visual, and faster and more complete. The globalized society uses network organizations and information systems, paraphrasing John Maynard Keynes [14] on classical education instead of classical economics: "Moreover, the characteristics of the classical education happen not to be those of the economic society in which we actually live, with the result that its teaching is misleading and disastrous if we attempt to apply it to the facts of experience."

This implies that learning methods should have features such as:

- Effectiveness: the power to achieve the learning objectives. To learn, one has to give meaning to information and communication, which can be achieved in the best way within networks where people communicate, cooperate and negotiate. Connectivity to create cooperative and creative 'learning by doing'.

- Efficiency: the power to optimize inputs in order to realize the learning objectives.

- Flexibility: the power to adapt fast changes so that the effectiveness and efficiency still can be achieved. Each entrepreneurial game simulation (explained later) is different and the dynamics of complex systems are characterized by new elements which arise due to the creativeness of the participant. This requires anticipation to keep the learning method up to date and running, continuous improvement similar to the Kaizen philosophy.

- Creativity: the power to bring in the changes which result in the future learning methods still will be effective, efficient and flexible. Learning methods themselves have to create new learning opportunities.

Contemporary professional education should develop more effective, efficient, flexible and creative learning methods for a better fit in this mindset of the new generation. So we postulate that the focus has to be on creating an authentic learning environment based on a demand driven, pull strategy, as the development of contemporary skills is far more demand driven than supply driven. For example Illeris [15] in his "Contemporary theories of learning", points out that 'the program offered must not only have an acceptable, interesting and challenging content, it must also contribute to an acceptable positioning in relation to contemporary trends on the youth lifestyle market, and it must be organized in ways and by teachers who are in harmony with the personal needs of the young learners'.

In our view the main change is the demand driven change in teaching, caused by a demand driven learning. Learning by doing has an $80 \%$ retention rate, making 'learning by doing' one of the most effective forms of learning (Sousa 2006).

Moreover, learning in the present times has to be both "connected" and "collaborative" to be an effective method of

1 paraphrasing Keynes, John Maynard, The General Theory of Employment, Interest and Money, p3, “...Moreover, the characteristics of the special case assumed by the classical theory happen not to be those of the economic society in which we actually live, with the result that its teaching is misleading and disastrous if we attempt to apply it to the facts of experience." 
learning. An authentic learning environment should make connected and collaborative learning possible. Indeed, our educational system should change its educational approach towards using more "authentic learning environments" thereby creating a context where the characteristics of the mindset of the new generation are the standard. These characteristics need to be developed explicitly in the teaching methodology.

\section{Creating an Authentic Learning Environment and Use CRAP}

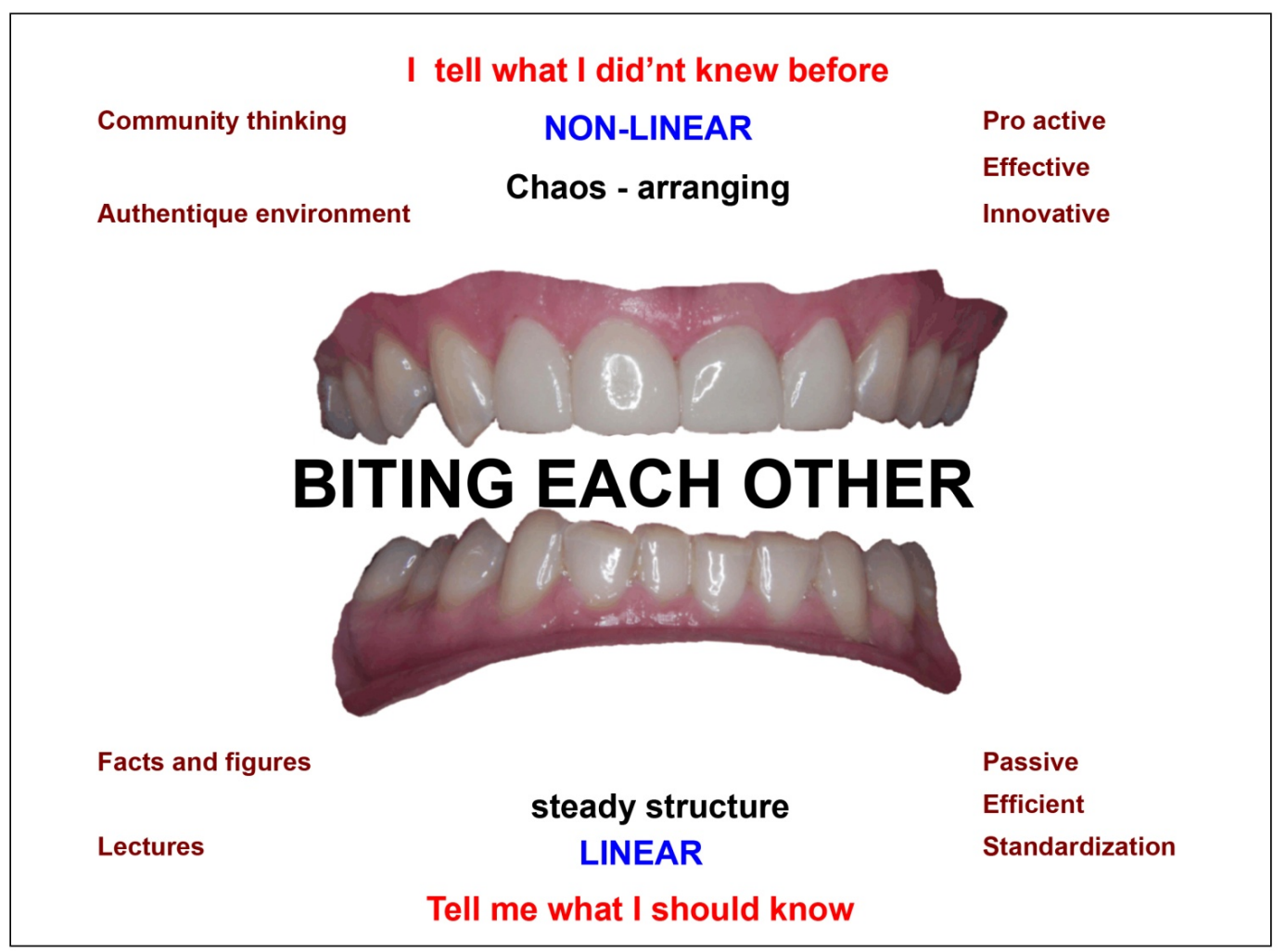

figure by: Adriaan Nieuwenhuis

Figure 2. Opposed Methodologies: They bite!!

The non-linear learning process is conflicting with the linear learning processes. Nevertheless, the effectiveness of the learning process should be stated by the students. A linear learning process is guided by the structure based on "tell me what I should know" (push learning).

Because there is a lot of uncertainty in de learning process as well as the fact that the learning process is complex, the assessment of this learning process needs a specific assessment system that both shows the performance of the individual and of the group.

The action point system is based on the responsibility of students for their own learning processes, hence the statement, "I will tell you what I have learned" (pull learning). Added to the action points is also the time spent on the action points, so the students are responsible of measuring their own learning process, both in achieved action points as in study time spent. Extra information is added in their individual digital portfolio.

So a complex learning process with uncertain outcomes can be realized within the context of individually realizing the action points method (PACT, Process Action Coordination Tool), where individually and group wise the action points are registered in a dynamic action list. Each session, based on several years of experience, on average will lead to some 6-10 action points. The action points list starts with number one, and when it is completed the action point vanishes and at each session new action points are added to the action points list. At the end of the course, the total number of action points gives a good indication of the performances of each group as well as of each individual. 


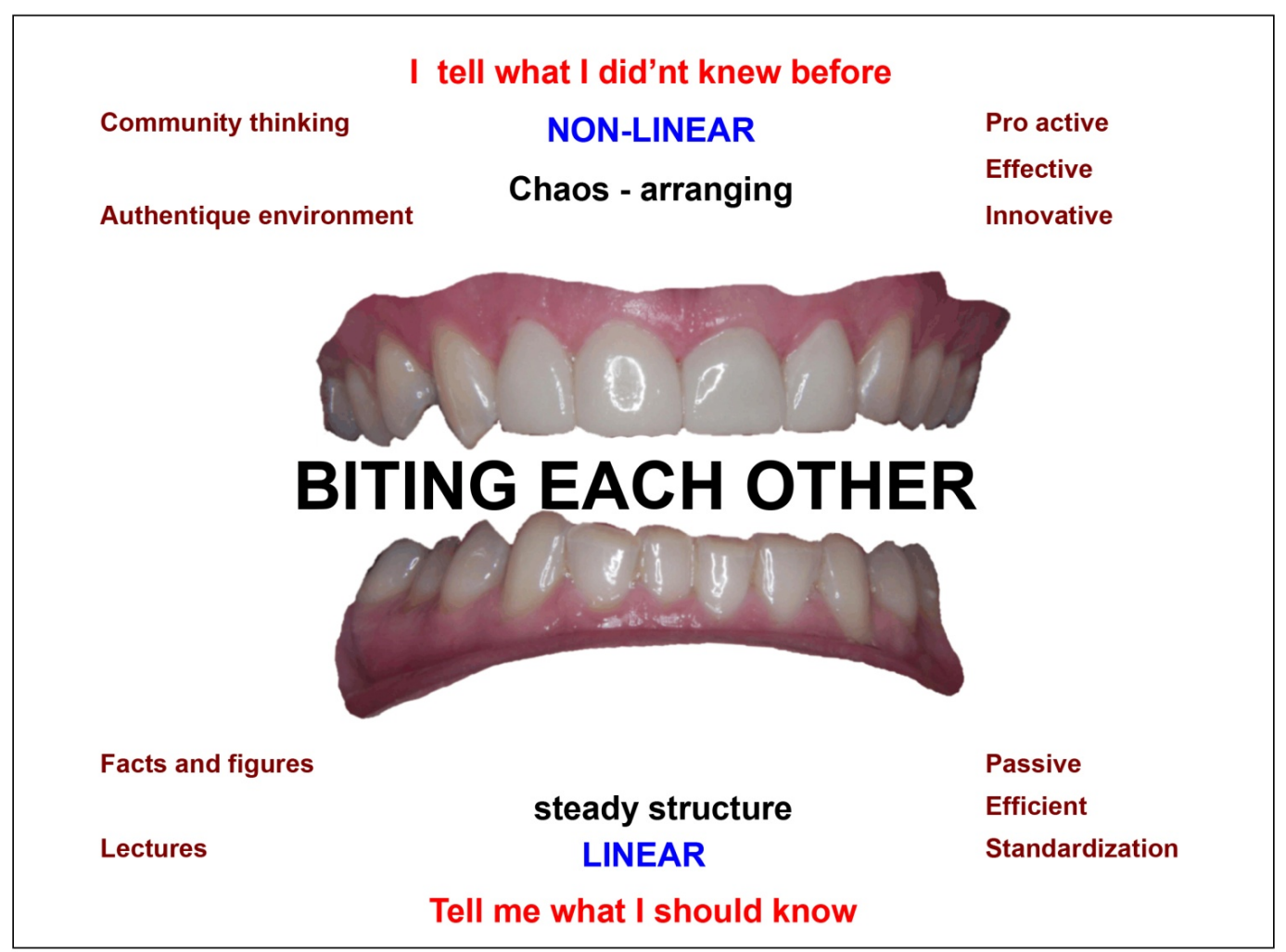

Figure 3. Slide PACT

As pointed out, the responsibility of the learning process is transferred to the students, and represented by individual action point's portfolio (CRAP / coordination registration action points) and the group action point's portfolio of group wise realized action points (Group-CRAP). In the portfolios there is also a registration of the hours studied to justify all Study Hours (SBU).

The portfolios are mainly digital with a short written explanation, which starts with the authenticity statement that all presented realizations is conducted by the person him/ or herself.

Hierbij verklaar ik dat ik bovenstaande werk zelf heb gedaan.

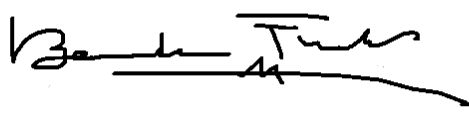

Benedikt Fuchs

Figure 4. Authenticity Statement: Hereby I declare that I did all the work myself

\section{Results of Several Courses of Conceptual Thinking}

In the second year course of Conceptual thinking the big line is to learn, recognize and experience creative thinking and apply it effectively in an authentic learning environment with real and realistic assignments. In almost every sector and business organization the need exists to change and to innovate continuously their products and services. Nowadays the development of internet makes knowledge accessible to anyone in the globalized world. In business and other sectors of our society there is an increasing need for innovative people who can think "out of the box" and who can apply their creative and concept-thinking, using the almost unlimited opportunities to adapt the available knowledge. Nevertheless, it requires a mindset which is open for creative solutions, a mindset you want to acquire and learn.

The assessment is at the end of the course by presenting the results of conceptual thinking to the specific client who has asked for specific innovative solutions in the form of an assignment.

Examples of such assignments are:

- Find innovative concepts for the tourism and recreation which stays overnight at bed \& breakfast companies in the South/Eastern part of the province Drenthe.

- Find innovative concepts for applying specific LED lights in organizations.

- Find innovative concepts for a language game.

- Find innovative concepts in for recreation in the German /Dutch border region of the Bourtanger Moor.

- Find innovative concepts for the "seniors-economy" in this region (for example organizing a new symposium grey/gold 4).

- ...etc.

The theory of De Bono [1] is used to find innovative 
concepts, especially the "random word" method is very effective. This leads to many creative ideas which can be organized according to the their originality (low, high) and the possibility to realize the idea (low, high). A technique developed by the Belgian COCD [39]: the COCD box (though we apply it during the idea generation and not after as they do).

An example of a simple idea that has been used from the "senior-economy" topic, was the idea to customize mobility scooter as if it was high speed car.

This authentic learning environment showed the effectiveness of a pull strategy, initiated by a real assignment and effective by the experience of positive emotions: success drives the success. It also made clear that the authentic context of this learning process is realized by the key characteristic that results of creative thinking in finding these new concepts, is the creating of added value.

The presentations were held for entrepreneurs, who could benefit from the innovative concepts. They had to spend their time and energy to validate the presentations and expect at least some "good ideas" for their invested time.

Meanwhile the system of G-CRAP and CRAP has been applied in more courses. For example the course "Trade and Globalization", where students had to advise on opportunities for specific shuttle trains, a real assignment from an international project team. Also the system has been applied in the course "Materials Management", where the PBL method of learning had to be applied, two different excursions to two different companies had to be prepared, while at the end of the course the students had to present in groups "what they had learned" to the representatives of the companies who had organized the excursions for these students. Thereby giving opportunity to the students to show that there had been an effective (or in some cases, not so effective) learning process.. Whatever the case - successful or not - CRAP and G-CRAP elaborated that very comprehensibly. G-CRAP is just representing small successes in an orderly, systematic way, thereby measuring quite simple the complexity of an effective, efficient, flexible and creative learning process.

\section{Conclusions}

Contemporary education needs an educational method where students have to acquire competences in a setting that has all the characteristics of new teaching: twitch speed, multitasking, connected, collaborative, etc. Nowadays this is the standard context for any job. Communication is more complex, visual, and faster and more complete. The globalized society uses network organizations and information systems to create added value. The 'connectivity learning' demands new approaches to monitor and coordinate collective learning processes - a demand driven change in teaching, caused by a demand driven learning of the new generation.

Using the system of PACT and by incorporating $C R A P$ (coordination registration of action points) and G-CRAP, (group coordination registration of action points) it is possible to integrate and apply the connectivity opportunities in lessons, to coordinate and measure learning progress, both individually and collectively.

To regard each lesson as a meeting, the techniques of a meeting can be applied to measure, assess and coordinate learning processes. The steps towards these learning goals can be divided in individual and collective action points which have to be carried out. Action points are kind of mini-projects which have to be conducted by the students. New connectivity opportunities like active boards in combination with internet make it possible to have the actual information of the progress of the learning process immediately visible for the whole group.

Action points list
During this module we worked with an action points list, by which everybody knew that what was
expected of them, making it clear who had to do what. I have gained a positive experience through this
and I plan to use this tactic more often. Also a genius program - that we (unfortunately) came across
only now - is Dropbox. This program we used as a standard when we worked in projects together.]
Merlijn van Zon
Portfolio Conceptueel Denken
GCD, 2011-2012

Figure 5. Example from a portfolio: 
1304 Teaching and Learning Economic Creativity: How to Overcome Uncertainty in Realizing Creative New Concepts That Have a Value? How the CRAP System -Coordination \& Registration of Action Points and External Assessment Generates Possible Solutions to Create Value of New Concepts?

Students carried out these assignments, using CRAP and G-CRAP (see appendix). The monitoring of the study and learning process is organized in cooperation with the clients who gave the assignments, and during the process play role of a coach. This authentic environment showed the effectiveness of a pull strategy, initiated by a real assignment and effective by the experience of positive emotions: success drives the success. It also made clear that the authentic context of this learning process is realized by the key characteristic that is creating added value.

\section{Value Originality}

Since competences are a combination of skills, attitude and knowledge to be successful in a professional environment, a demand driven learning process should focus on success. Considering a lesson as meeting to coordinate a complex learning process, creates a pull system, in which learning is based on realizing action points both as an individual and as a collective group. Using the process of coordination by action points, like CRAP and G-CRAP creates a dynamic overview that optimizes effectiveness, efficiency, flexibility and creativity within connectivity learning. Hence, "a positive experience" of successes that supports learning and teaching.

So we postulate that the focus has to be on creating an authentic learning environment based on a demand driven, pull strategy, as the development of contemporary skills is far more demand driven than supply driven. So we pose again a question: doesn't learning of creativity require far more "pull"-learning instead of "push"-teaching?

Indeed, our educational system should change its educational approach towards using more "authentic learning environments" thereby creating a context where the characteristics of the mindset of the new generation are the standard.

The value originality is in the question: how to determine the value of creativity? We experienced that as teachers we cannot really determine the value of new concepts, resulting from creative thinking. To determine this value, the usefulness of the new concepts can be assessed by entrepreneurs who will use it for their specific purposes.

The marks on the presented new concepts given by the entrepreneurs seldom reach the level " 8 " (good), "9"(very good) or even "10" (outstanding), on the scale used in The Netherlands from " 0 " to " 10 ". In the education system a " 6 " is sufficient to pass, a "7" is more than sufficient.

One of the students expressed this difference in assessing performances beautifully:(, Van der Sijde and Roelofs [16] "In education there is a critical dividing line between sufficient (pass) and not sufficient (fail), but in business there is a critical dividing line between good and not good. That is something entirely different".

\section{REFERENCES}

[1] E. De Bono. Think!: Before It's Too Late, Random House, UK, 2010, p.21.

[2] W. Veen. Homo Zappiens, opgroeien, leven en werken in een digitaal tijdperk. Pearson Education Uitgeverij, Nederland, 2009.

[3] M. Prensky. Digital game-based learning. New York: McGraw-Hill, 2001

[4] Ken Robinson [4] in RSA Animate - Changing Education Paradigms at https://www.youtube.com/watch?v=zDZFcDGpL4U)

[5] Bradshaw G, Langley P, Simon H. Studying Scientific Discovery by Computer Simulation. Science. 1983;222(4627):971-975.

[6] H.A Simon. What We Know about the Creative Process" in: R.L. Kuhn (ed.), Frontiers in Creative and Innovative Management, Ballinger, Cambridge, MA, 1985

[7] Bradshaw G, Langley P, Simon H. Studying Scientific Discovery by Computer Simulation. Science. 1983;222(4627):971-975.

[8] Oldham G, Cummings A. Employee creativity: personal and contextual factors at work. Academy of Management Journal. 1996;39(3):607-634.

[9] T. Amabile. Microscopic and macroscopic creativity. Journal of Social and Biological Systems. 1988;11(1):57-60.

[10] J. Waalkens. De intrinsieke relatie tussen ondernemerschap, innovatie en kenniscirculatie, Stenden university of A.S: Emmen/the Netherlands, 2010

[11] W. Veen, B. Vrakking. Homo zappiens: Growing up in a digital age, Network continuum education, London, 2006

[12] Veen, Homo Zappiens and the Need for New Education Systems, Proceedings OECD Conference, 2007

[13] P. Kotler, G. Armstrong, L.C. Harris, N. Piercy. Principles of Marketing, 6th European Edition, Pearson, England, 2013, p158.

[14] J.M. Keynes. The general theory of employment, interest and money. New York: Harcourt, Brace; 1936. p3.

[15] K. Illeris, Contemporary theories of learning, Routlegde, New York/London, 2009

[16] H.D. Roelofs, N. Van der Sijde. Handbook learning companies (5th ed.), Stenden university of A.S: Emmen/the Netherlands , 2005.

[17] Argyris, C., Schön, D. A. (1978). Organisational learning: A theory of action perspective. Reading, Mass. Addison Wesley.

[18] Coulther, Mary (2003), Entrepreneurship in ACTION, Prentice Hall

[19] De Geus, G., \& Van der Sijde. (2003). Kritisch toetsen of de toets der kritiek. Stenden university.

[20] Den Hartog, Deanne N en de Jong, Jeroen P.J. (2008) Innovative Work Behavior: Measurement and Validation, EIM Research Reports 
[21] Harford, Tim, (2011) “Adapt: Why Success Always Starts with Failure", , Little Brown, London.

[22] Anthony Herrington, Jan Herrington (2006), Authentic Learning Environments in Higher Education, Information Science Publishing (September 13, 2005)

[23] Illeris, Knud (2009), "Contemporary theories of learning", New York/London, Routlegde (2009)

[24] Meyer, Christopher, (2012). Standing on the Sun: How the Explosion of Capitalism Abroad Will Change Business Everywhere, Harvard Business Review Press

[25] Popper, K. P. (2006). Auf der Suche nach einer besseren Welt: Vorträge und Aufsätze aus dreißig Jahren. Piper

[26] Robinson, K. (2001) Out of Our Minds: Learning to Be Creative. Capstone: Edina Minnesota

[27] Roelofs, Henk , Samplonius-Raut, Shilpa (2010), The Edu-preneurial Pedagogic Method: providing risk and added value experience in a pull system for learning entrepreneurship, China-USA Business Review ISSN 1537-1514 October 2011, Vol.10, No.10, 993-1010

[28] Roelofs, Henk, Samplonius-Raut, Shilpa (2011), The edupreneurial method: an authentic environment as a base for effective education, Conference "New Values for the Development of Tourism and Society", School of Business Administration Turiba, Riga, Latvia.

[29] Roelofs, Henk Nieuwenhuis, Adriaan, Saleem, Rizwan (2012),Reference Creation As An Effective Learning System For Teaching Languages (Chinese, Hindi) In A Network Of Participants Using The Edupreneurial Method And
Zapp-Learning. First Steps Towards Organizing An Unconscious Learning Methodology, Second International Conference on Language, Thought and Education: exploring networks...University of Zielona Góra (Poland)

[30] Siemens, George (2006), Knowing Knowledge, Lulu.com

[31] Smith, M. K. (1999). Learning theory. In The encyclopaedia of informal education. Retrieved from www.infed.org/biblio/b-learn.htm

[32] Sousa, D. A. (2006). How the brain learns (2nd ed.). Corwin Press.

[33] Veen, W. (2009). Homo Zappiens, opgroeien, leven en werken in een digitaal tijdperk. Pearson Education Uitgeverij.

[34] Waalkens. J, Van der Vegt. G (2013), On entrepreneurship education, Stenden University of A.S: Emmen/the Netherlands

[35] Zualkerman, I. A. (2006). A framework and a methodology for developing authentic constructivist e-learning environments. Educational Technology and Society, 9(2), 198-212.CISCO Systems Inc.(2006) "Dynamic Learning environments for a competitive workforce

[36] http://www.bangcreations.co.uk/

[37] http://www.ce-ondernemerschap.nl/startende-ondernemers/o pleidingen-voor-startende-ondernemers/mbo-ce-ondernemer schap

[38] http://www.onderwijsraad.nl/publicaties/2014/een-eigentijds -curriculum/volledig/item 7128

[39] http://www.cocd.org/kennisplatform/cocd-box/ 